\title{
NEW TOWNS DEVELOPMENT: A WAVE OF THE FUTURE PLANNING PRACTICES IN NEPAL
}

\author{
Kedar Dahal* \\ Krishna Prasad Timalsina
}

\begin{abstract}
Increasing urbanization has been a major challenge to tackle issues relating to population growth, housing, infrastructure development and urban management in Nepal. Initiatives have been taking by the stakeholders of urban sectors in different course of action plans. New town development, smart city development, preparation and implementation of various strategic plans and action plans are some of the initiatives undertaken by the Ministry of Urban Development, Government of Nepal. At present, the Ministry of Urban Development is preparing intervening plans and programmes to 40 towns for planned urban development in Nepal. Some of these towns are already in pace of development and some others are in infancy stages. Balance urban development strategy so far is a strategy of government of Nepal however theory of political economy of development is inherently coming in selection of the towns, and basically in implementing the plans. Therefore, most of the prepared action plans are in question of effective implementation. Among the prioritized new towns of Nepal, some of these towns particularly smart cities are in very infancy stages of infrastructure development in which 'smartness' itself falls into huge dilemma. Therefore, more challenges are added in implementing the smart cities into action plan. However, new towns of Hilly and TaraiMadhesh area will definitely provide the opportunities to cater population and create more opportunities. In this context, this study focus on the new town development and their spatial distribution in Nepal through the collection of primary information and review of previous literature.
\end{abstract}

Key words: New towns, tarai-madhesh, smart city, plan intervention, development, corridor

\section{INTRODUCTION AND OBJECTIVE}

The history of urban growth in Nepal begins since 1944. Since then Nepal has also experienced a rapid urbanization. Many small towns

\footnotetext{
* Dr. Dahal is Associate Professor in Geography, Tri-Chandra Multiple Campus, Ghantaghar, TU, and Mr.Timalsina is currently associated with the Department of Geography, Tri-Chandra Multiple Campus, Ghantaghar, TU.
} 


\section{NEW TOWNS DEVELOPMENT: A WAVE OF THE FUTURE PLANNING ...}

and cities were developed in around the Kathmandu Valley and the Tarai Region of Nepal. In 1952-54 there were 10 urban centres delineated in Nepal. Among them, five were in the Kathmandu Valley and remaining five were out of Kathmandu Valley. The number of urban centres rose up to 16 in 1961 and 23 in 1981. Similarly, the number of urban centres in 1991, 2001 and 2014 were recorded 33, 58 and 191 respectively. At present federal restructuring context of Nepal, the government has declared 263 municipalities with 6 metropolitan cities and 11 sub-metropolitan cities. According to population census 2068, total urban population has been increased by 58.38 percent considering present municipalities of Nepal (CBS, 2012). Moreover, the number of towns and market centres has been increasing with the construction of new roads and highway in different geographic regions of Nepal.

Increasing population pressure in the newly emerging towns have made more difficult to provide basic physical and social infrastructure and services. The local bodies have increasingly been facing more difficult to develop urban areas in a planned way. During 1960s, many people from hill and mountain were resettled in the Tarai due to displacement from natural disaster (DUDBC, 2007).During the decade, internal migration increased inTarai and larger cities of Nepal. Government also focused to larger cities and towns for planning and infrastructure development which increased uneven development among the towns and cities of Nepal (Gurung, 1969). This again became major factors of Hill to Tarai and Rural to urban migration in Nepal. In 1970s, Regional Development concept was initiated in Nepal. Four growth poles and several other growth centres were identified in order to reduce the regional disparity in Nepal. Biratnagar-Dhankuta, HetaundaKathmandu, Bhairahawa-Jomsom, Nepalganj-Jumla were identified as a main growth poles. The growth pole hypothesis was to establish northsouth linkages in the movement of goods and services, trade and people with the view to coordination and integrated development activities within the country (Dahal, 2005). Series of north-south growth axis linking the diverse region have been defined. Each growth axis was planned to connect road. These roads will link a series of growth centres where development efforts will be concentrated in order to achieve full economics of scale and encourage agglomeration economies (Gurung, 1969). The important aspects of the growth centres is the positive nature of polarized development as it takes place and the mechanisms whereby the growth centres spreads growth to the surrounding areas. Master plan of four regional headquarter (e.g. Dhankuta, Pokhara, Surkhet and Dipayal) was prepared and implemented 
in this period (DUDBC, 2007). But proper implementation of these master plans was not success due to lack of institutional and legal mechanisms.

In 2007, the Government of Nepal enacted and has been implementing National Urban Policy for balance urban development in Nepal (DUDBC, 2007). The policy was implemented to develop balance urban growth in the country by prioritizing investment to the lagging regions for development of regional cities and intermediate towns.In this context with an objective of reducing migration to Kathmandu and other larger cities, encouraging planned development of potential hill cities and building infrastructure that can facilitate and attractthe population in the hilly cities, the Government of Nepal has started to develop 10 new towns in Mid-Hill Highway corridor of Nepal since 2068 B.S. It was one of the turning points of the government to develop planned cities in Hilly areas of Nepal. Moreover, two new towns in Hilly Region namely; Bheriganga in Surkhet District and Bhingri in Pyuthan District are also in execution phase of the government of Nepal. Recently, government of Nepal has executing plan intervention in the Tarai Towns of Nepal, particularly in the growing potential towns of Tarai-Madhesh Region. 15 new towns from the Tarai region have been selected for plan interventions (DUDBC, 2074 B.S.a.). Main objective of developing new towns in Tarai-Madhesh Region is to contribute balance urban development and develop liveable cities in TaraiMadhes area of Nepal so that stagnant areas would be served and connected by the newly developed towns of the Tarai-Madhes region.

Likewise, 13 smart cities are also in process of plan intervention by the government of Nepal. Lumbini, Nijgadh and Palungtar are already entered into the phase of plan preparation of smart cities and other ten smart cities namely: Dhankuta, Mirchaiya, Kavre Valley, Chandrapur, Bharatpur, Waling, Tulsipur, Dullu, Tikapur and Amargadhi are in process of plan preparation (DUDBC, 2074 B.S.). All together 40 growing cities of Nepal are in priority focus of the government for plan intervention and execution for urban development to foster balance urban development as postulated in the National Urban Policy of Nepal. Therefore, this study focuses on the spatial distribution of new towns in Nepal with reference to urban development and planning practice in Nepal.

\section{METHODS AND DISCUSSION}

This article is based on both primary and secondary data which was collected during the process of new town selection, plan preparation of both Mid-hill Highway towns and Tarai-Madhesh towns of Nepal in different 


\section{NEW TOWNS DEVELOPMENT: A WAVE OF THE FUTURE PLANNING ...}

periods of 2011, 2015 and 2016. Town selection criteria were prepared by reviewing the existing literature and documents in close coordination with implementing agency such as Department of Urban Development and Building Construction (DUDBC) and New Town Project Coordination Office (NTPCO).In case of new town selection in Mid-hill highway corridor region, primary criteria such as land availability, situation of drinking water, economic development potentiality (industrial development and availability of natural/human resources) were used. And, secondary criteria such as location, transportation and communication, administrative hierarchy of the town, rural-urban linkages, non-agricultural activities, existing large scale investment in the vicinity of the townavailable social/community services were used for town selection (DUDBC, 2068 B.S.).

In selection new towns of Tarai-Madhesh Region, criteria such as land availability, population, density, nodal junction, economic development potentiality (market centre, industries), population engaged in non-agricultural activities, sources of drinking water, in-migration rate, availability of government services, literacy rate, access of road etc. were used (DUDBC, 2074 B.S.). Potential new towns from the Tarai-Madhesh area were selected through the series of screening process from the list of potential towns. In studying the specific potentials of a particular town, fieldwork was conducted. Participatory fieldwork is the central and important method for collecting the primary information as the method can well explain the contextual situation (Timalsina, 2011). Observation (participatory and non-participatory), key informants interview, informal conversational interview, participatory consultations were used to collect primary information whereas secondary information were collected from published and unpublished literature/documents. In planning process, participatory interactional consultations were done to select towns in MidHill Highway Corridor and Tarai-Madhesh Area.

\section{New towns in the mid-hill highway corridor}

The Mid-hill Highway-also called Pushpalal Highway which starts from Chiyo Bhanjyang of Panchathar District in the East and ends at Jhulaghat of Baitadi District in the Far-west connecting hilly districts of Nepal. With a length of $1776 \mathrm{~km}$, this highway connects 24 hilly districts directly affecting about 7 million people (DUDBC, 2068 B.S.). It is envisaged to provide easy access to many of the less accessible and often stagnant communities in the Mid-hill area of Nepal. Marked by low income and increasing out-migration of unemployed youthas well as poor access to public services, these hilly communities are expected to benefit from the 
easier access to markets in Tarai and other higher level market centres of the Region. The government brought this ambitious project of developing cities to reduce growing human pressure in the big cities including the Capital City, Kathmandu (DUDBC, 2068 B.S.). It is believed that with the completion of the project, migrations to the new cities would grow and population would be hold in these towns by providing services and creating marketing opportunities there. Newly developed towns would create ample of opportunities within the new town and thereby it reduces out migration. It was one of the main strategies of balance urban development in the Hilly Region as per objectives stated in the National Urban Policy.

The new towns of Mid-Hill Highway corridor are: Phidim (Panchthar), Basantapur (Terhathum), Khurkot (Sindhuli), Baireni-Galchh (Dhading), Dumre-Bhansar (Tanahun), Burtibang (Baglung), Chaurjahari (Rukum), Rakam-Karnali (Dailekh), Safebagar (Achham) and Patan (Baitadi). These towns belong 2 in each Development Region which seems adoption of balance urban development strategy in the hilly region (DUDBC, 2068 B.S.).Distribution of 10 new towns along the Mid-Hill Highway Corridor of Nepal is shown in Map 1.

Map 1: Distribution of 10 New Towns along the Mid-Hill Highway of Nepal

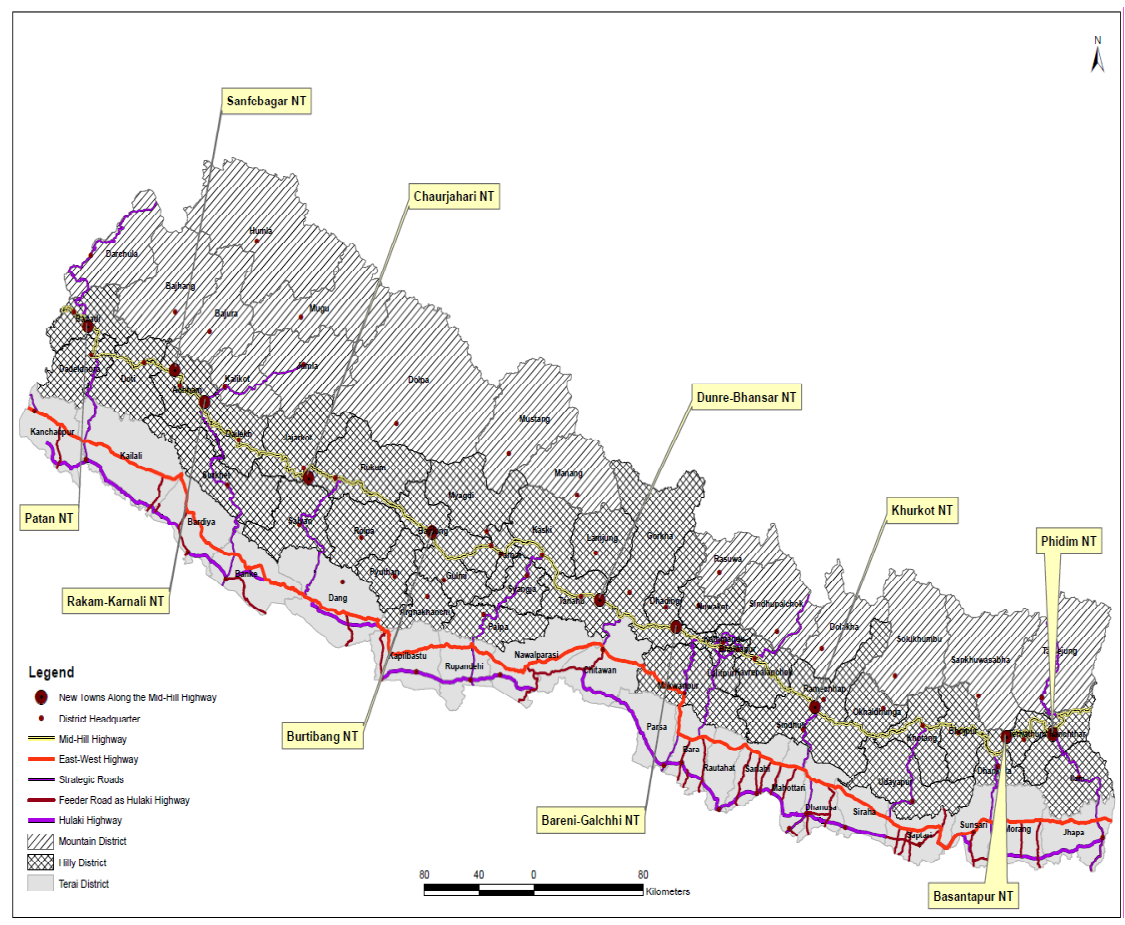


144 NEW TOWNS DEVELOPMENT: A WAVE OF THE FUTURE PLANNING ...

At present, the government has been investing in its infrastructure projects specially road improvement, land development, drainage construction, construction of sanitary land fill site, water supply and construction of other urban infrastructure projects in the new towns. However, as being hilly towns and increasing tendency of pre-occupancy of land by the elites, land availability for construction of public infrastructures has been one of the growing challenges in most of the these towns (NTPCO, 2073 B.S.). Therefore, new town project office is increasingly facing challenges to acquire land for construction of urban infrastructures in these towns. In addition to this, due to the lack of political commitments, cooperation and low capacity of implementing agencies, implementation of plans have been quite challengeable. Allocated budget expenditure pattern in most of the towns seems very low.

\section{New towns in the tarai-madhesh region}

The government of Nepal has also started to develop new towns in the Tarai-Madhesh Region of Nepal. The government has already selected 15 new towns in the Tarai-Madhesh region with an objective of expandingsettlements in the Tarai-Madheshto promote planned urbanization. The new towns are located either in the East-west Hulaki Highway or feeder roads connecting East west highway to district headquarters and other towns of Tarai Region. These new towns are: Gauriganj (Jhapa), Rangeli (Morang), Sambhunath (Saptari), Balawa (Mahottari), Manara (Mahottari), Ishworpur (Sarlahi), Brahmapuri (Sarlahi), Katahariya (Rauahat), Maulapur (Rautahat), Mahagadhimai (Bara), Bardaghat (Nawalparasi), Gadhawa (Dang), Rajapur (Bardiya), Bhajani (Kailali) and Belauri (Kanchanpur) (DUDBC, 2074 B.S.a). Distribution of 15 new towns of Tarai- Madhesh Region is shown in map 2. 
Map 2: Distribution of 15 New Towns in the Tarai-Madhesh Region of Nepal

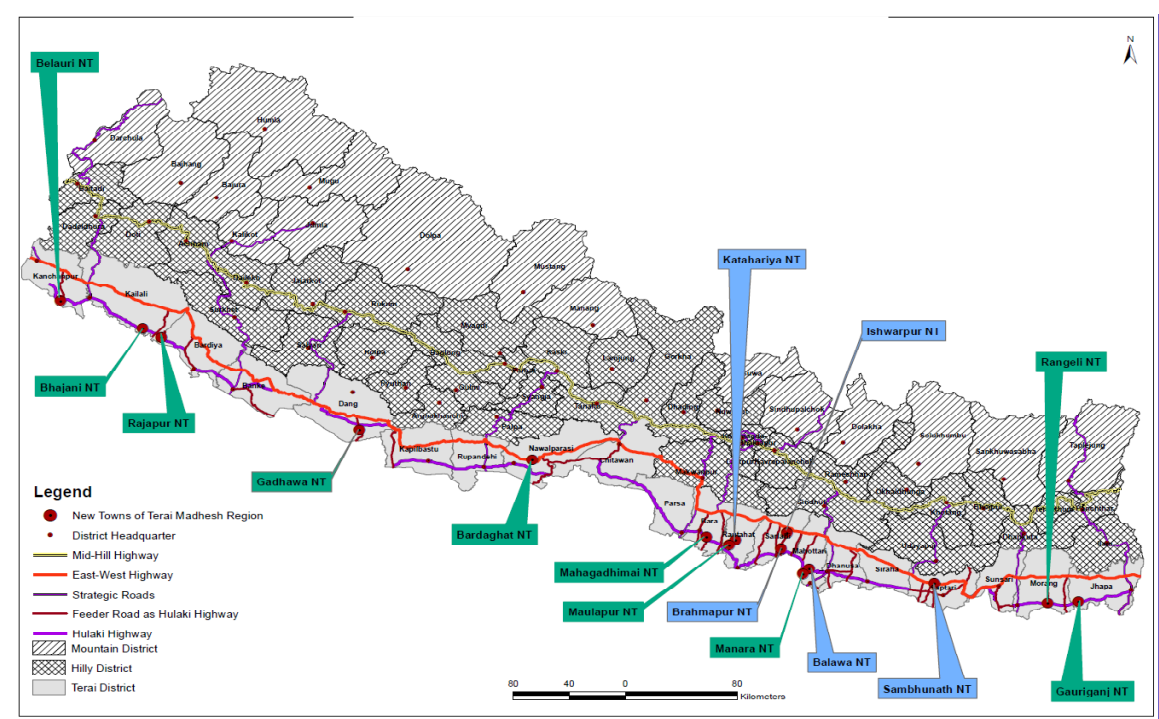

There are two different views regarding the Hulaki Highway alignment. One view is that only the Highway passing through East to West parallel to East-West Highway (Mahendra Highway) is called Hulaki Highway whereas another view is that the East-west Hulaki Road as well as feeder roads connecting to various district headquarters and towns of Tarai Region of Nepal are also called Hulaki Road. Chairman of the Development Committee, House of Representative, Mr. Rabindra P. Adhikari arguing the second view explains:

Most people think that Hulaki highway is only the highway extending east to west parallel to (East-West) Mahendra Highway of Nepal, but we all should keep in mind that 32 sections of north-south feeder roads of $917 \mathrm{~km}$ length connected various district headquarters and towns of Tarai, and $975 \mathrm{~km}$ length east-west Hulaki roads with total length of 1792 km roads collectively called Hulaki Highway (Adhakari, 2017).

Arguing to firstview, Honourable Ministry for Urban Development Mr.Prabhu Shah in a conversation explains that 'there is no Hulaki Highway passing north-south in Nepal. The north-south roads are feeder roads, just put them in a basket of Hulaki Project for construction purposes. As I have been struggling throughout my life long political career to this Hulaki Road 
146 NEW TOWNS DEVELOPMENT: A WAVE OF THE FUTURE PLANNING ...

of Tarai, How I can agree the feeder roads are Hulaki Highway.Therefore, Hulaki Highway is only those roads passing East-west in the Tarai Region of Nepal. Therefore, Hulaki Highway is only those roads passing East-West in the Tarai region of Nepal.

A local resident and politician of Ishworpur supporting to second view says:

I am the resident of this town, and have been working for the public when I started my political career. The road connecting to Phuljor (Mahendra Highway)-Bayalbas- Tribhuwannagar is a Hulaki road which every people know here in Ishworpur.

There is no doubt that some north-south feeder roads are Hulaki roads. Studying to those statements as well as fieldwork impressions through consultation at local level, it indicates that Hulaki Roads are in two different categories; one-East-West Hulaki road runs some 20 to 30 kilometres south, parallel to the East-West (Mahendra) highway and twoan approach or feeder road connecting (North-South and sometimes parallel to East-West Hulaki road) to the districts head-quarters and other towns of the Tarai-Madhes areas of Nepal. However, both categories of Hulaki roads are considered the lifeline of the Tarai region, as it links 20 districts, maintowns and settlements of the Tarai with a good road networks. The government believes that new cities to be developed in the Tarai-Madhesh would lead to the expansion of settlements in a systematic way in the Tarai-Madhesh region thereby discouraging the construction of unplanned towns. It is also expected to develop selected towns as new cities with good provision of physical and public infrastructures which will be the pulling centres of population through the surrounding areas thereby discouraging the out migration.

While selecting potential towns of Tarai-Madhesh, primary criteria such as road connectivity, minimum population threshold, basic level of existing infrastructures were considered. After then, detail criteria such as availability of land, population, density, potentiality of economic development, population involved in non-agriculture sector, availability of water resources, migration, situation of government facilities, literacy and access to road facilities were used (DUDBC, 2074 B.S. b). Based 
on the defined criteria new towns were selected for further planning and development intervention. The 'Political Economy of Development' (Fox, 2013 ) in town selection is perceived and reflected in most of the town development in Nepal. Inherently within the theory of 'Political Economy of Development', 10 towns have been selected from different districts as 'Hulaki Highway Towns' whereas 5 towns have been selected as 'TaraiMadhesh Towns'. However, government of Nepal is planning to develop all these 15 towns as New Towns of Tarai-Madhesh Regionas 'Emerging Towns' which is in itself a good initiation. It should also be noted that Central Tarai area is one of the focussed area of urban development of the government of Nepal and therefore, more number of new towns are selected from central Tarai region. It is expected that these new towns willget an opportunity of development as important cities in this region and thereby will be established as a strategic towns.

Further, the government of Nepal is planning to prepare an integrated urban development plan of the selected new towns for systematic plan development for intervention. The integrated urban development plan will cover sectoral plan such as physical development, social development, environmental management, economic development, institutional development, multi-sector alinvestment, disaster risk management(DUDBC, 2072 B.S.) etc. Yearly budget allocation would be made available on the basis of prepared integrated development plan of the towns. Therefore, the integrated urban development plan for the new towns will be importantway forward for execution of projects at town level for intervention.

\section{Other cities in pipeline}

Other cities are also in course of action for implementing urban development projects in Nepal. Two new towns-one each from Pyuthan and Surkhet district, are also selected for planning interventions. Bhingri, a new town, considering present Swargadwari Municipality, located at the edge of Madi River is one of the potential towns of Pyuthan district. It has potentiality of tourism and agriculture development for the basis of urbanization. Similarly, Bheriganga Valley is another new town located in Surkhet District covering present three municipalities namely Bheriganga, Gurvakot and Lekhbeshi. These municipalities are located at the Bheri River Valley covering lower level of Bheri River basin and upper hilly area 
148 NEW TOWNS DEVELOPMENT: A WAVE OF THE FUTURE PLANNING ...

(DUDBC, 2074 B.S.). The government is also planning to develop these new towns in a planned way and therefore, planning to establish a project office to execute plans and programmes (NTPCO, 2072). Smart cities are other towns that Nepal Government has recently been focussing for development. Three smart cities namely; Lumbini, Nijgadh and Palungtar are recently entered into conceptual planning phase. Other 10 smart cities namely; Dhankuta, Mirchaiya, Kavre Valley, Chandrapur, Bharatpur, Tulsipur, Tikapur, Dullu and Amargadi are in process of planning (NTPCO, 2074 B.S.). Among these smart cities, some are matured cities such as Bharatpur, Tikapur, Dhankura and Lumbini where as other cities such as Dullu, Palungtar, Waling are in infancy stages of development. Among these smart cities, 7 are situated in Tarai Region and 6 are situated in Hilly Region including Tulsipur.

In Nepal, concept of smart city has been coming into discussion among the planners and development practioners recently. A smart city is an urban development vision to integrate information and communication technology (ICT) in a secure fashion to manage a city's assets (MUD, 2015). These assets include local departments' information systems, schools, libraries, transportation systems, hospitals, power plants, water supply networks, waste management, law enforcement, and other community services (DUDBC, 2074 B.S. c). A smart city is promoted to use urban informatics and technology to improve the efficiency of services (MUD, 2015). ICT allows city officials to interact directly with the community and the city infrastructure and to monitor what is happening in the city, how the city is evolving, and how to enable a better quality of life. Basic characteristics of smart mobility are; smart home, smart society, smart energy, smart building, smart working, smart governance etc. (DUDBC, 2074 B.S. c). While looking into the concept of Smart City, two basic themes are very important to be linked with. They are database and database operating system (Technology). Database on the one hand is necessary to identify the existing urban status (population, infrastructures, services etc) and for linking it to the information technology, and technology itself is necessary to make urban service easier, safer, and guaranteedfor urban residence. These two are interlinked to each other which are the hurt of smart city. The concept of a Smart City goes beyond the transactional relationships between citizen and service provider. It is essentially enabling and encouraging the 
citizen to become a more active and participative member of the community, for example, providing feedback on the quality of services or the state of roads and the built environment, adopting a more sustainable and healthy lifestyle, volunteering for social activities or supporting minority groups (MOUD, 2015). Map 3 shows the distribution of new towns and smart cities in Nepal. If we look at the distribution of towns on the map of Nepal, Tarai Region of Central Nepal (province 2) has clustered more cities/towns. Among 40 towns, 11 towns are located in the province no 2 . This reveals that government of Nepal has given priority of urban development in this province. Moreover, 'political economy of development' again, to some extent, has reflected on this issue from the beginning of town selection and, of course, will effect on implementation of the project which is always there that development planners are frequently facing.

Map 3: Distribution of 40 Strategic Towns in Nepal

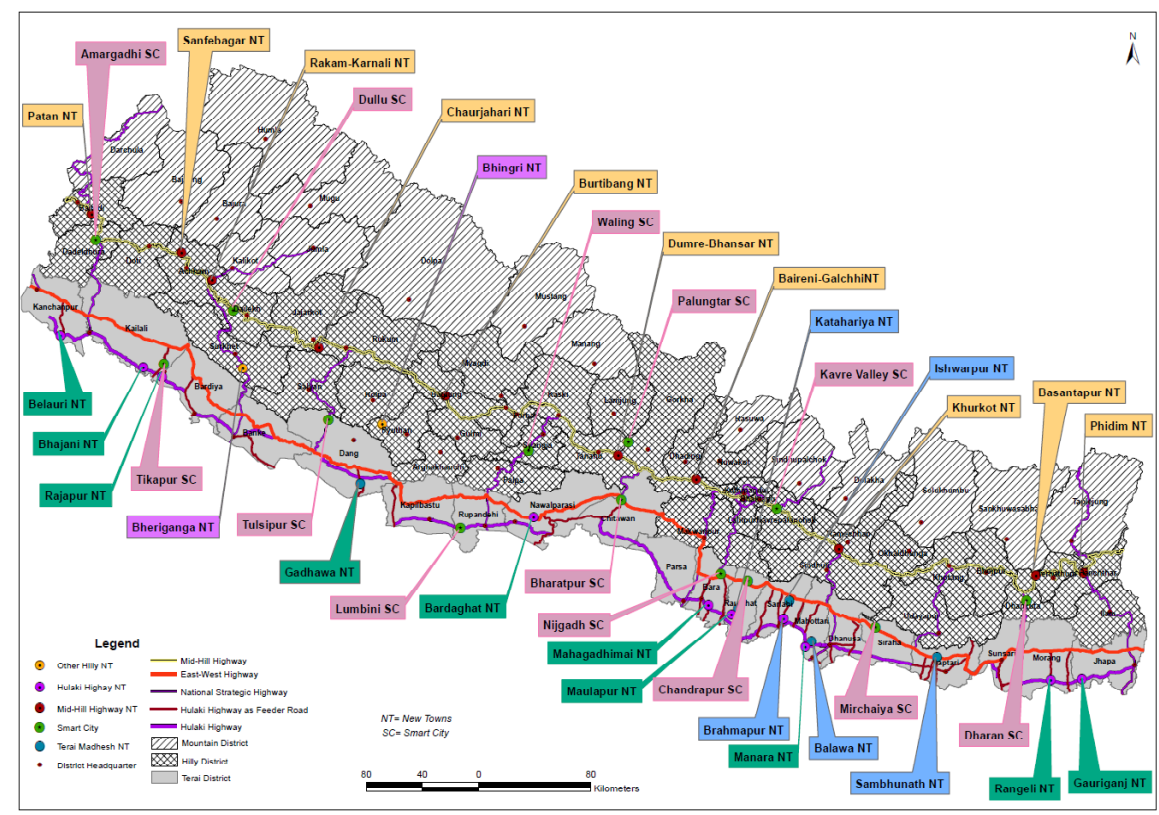

\section{CONCLUSION}

Nepal Government is putting its effort in planned urban development since 1944 and has been implementing various plans and programmes in the urban sectors. At present, the government is giving attention of urban 
development through new town development, smart city development, preparation and implementation of various types of other action plans under the Ministry of Urban Development, Department of Urban Development and Building Construction (DUDBC). The Department is preparing intervening plans and programmes to 40 towns for planned urban development. Among these towns, 15 new towns are located in Tarai-Madhesh Region, 10 new towns are located in Mid-Hill Highway corridor of Hilly region, 2 more new towns are also located in Hilly region- one each in Pyuthan and Surkeht district. Similarly, 13 smart cities are located both in Tarai and Hilly districts. While talking about the federal distribution of these 40 new towns, 11 new towns are from province no 2 . This means government is focussing to develop cities in lagging areas so that stagnant areas and population would be connected in the planned city network. Some of these towns are already in some pace of development and some others are in infancy stages.

Looking at the present planning practice in Nepal, future interventions tend to be more political and new planning approaches will be coming into front among the implementing agencies. Smart city will be more fashionable and political actors are pushing the terminology for catching up the public sentiments. However, smart city planning needs to be contextualized. First of all improvement and expansion of infrastructure development focusing on actual need of locals in most of the city plans will definitely come in the priority interventions. Present planning intervention has been observed that 'Political Economy of Urban Development' is played a role to some extent in implementing development plans into action. Hence, future wave of planning needs to be technological driven and actual need baseof locals rather than imposing some political interests. In other words, future planning wave should be 'apolitical' rather than a 'political' one which should address local community's actual needs.

\section{WORKS CITED}

Adhikari, R., (2017). Hulaki Rajmargara Madhes ko Bikas (in Nepali). Kantipur Daily Newspaper, p.5. 
CBS., (2012). National population and housing census (village development committee and municipality). Kathmandu: Central Bureau of Statistics, Government of Nepal.

Dahal, K., (2005). Research note: revitalization of the regional development agenda in Nepal: Lessons from British model. Contributions to Nepalese Studies. Vol.32. (2), Kathmandu: CNAS, TU.

DUDBC., (2007). National urban policy. Kathmandu: Ministry of Physical Planning and Works, Government of Nepal.

- - (2013). Planning norms and standards. Kathmandu: Department of Urban Development and Building Construction, Ministry of Urban Development, Government of Nepal.

- - - (2014). Business plan. Kathmandu: Department of Urban Development and Building Construction, Ministry of Urban Development.

- - (2068 B.S.). Feasibility study of potential towns in mid hill highway corridor. Kathmandu: Governemnt of Nepal.

- - - (2072 B.S.). Preparation of integrated development plan of phidim and basantapur new towns. Kathmandu: Governemnt of Nepal.

- - - (2074 B.S.(a)). Feasibility study of new towns in the tarai-madhesh area of Nepal. Kathmandu.

- - - (2074 B.S.(b)). Preparation of strategic urban development plan of new towns in Pyuthan and Surkhet district. Kathmandu: DUDBC.

- - - (2074 B.S. (c)). Preparation of concept and indicators for smart cities in Nepal. Kathmandu.

Fox, R. S., (2013). The Political Economy of Urbanization and Development in Sub-Saharan Africa. London: An Unpublished PhD Thesis, submitted to London School of Economics and Political Science.

Gurung, H., (1969). Regional development planning for Nepal. Kathmandu: National Planning Commission, Government of Nepal.

MOUD., (2015). National urban development strategy. Kathmandu: Ministry of Urban Development, Government of Nepal.

MUD., (2015). Smart cities, mission statement and guidelines. India: Ministry of Urban Development. 
152 NEW TOWNS DEVELOPMENT: A WAVE OF THE FUTURE PLANNING ...

NTPCO.,(2073 B.S.).Economic developmentplan of Phidimand Basantapur new town. Kathmandu: New Town Project Coordination Office.

Timalsina, K.P., 2011. Struggling for livelihood: Making a living in the urban informal sector. Germany: VDM Verlag \&. Müller. 